\title{
Interaction between Phytophthora infestans and Tissue Gultures of Solanum tuberosum
}

\author{
BY D. S. INGRAM AND N. F. ROBERTSON \\ Department of Botany, The University of Hull
}

(Received 15 April 1965)

\section{SUMMARY}

It has been shown that tissue cultures of Solanum tuberosum var. Majestic (susceptible) stimulated the growth of Phytophthora infestans. A similar stimulus was produced by cell suspensions of the $S$. tuberosum var. Orion (resistant), but was not manifested by larger tissue aggregates of this variety. The failure of Orion tissue aggregates to stimulate was independent of the size of the fungal inoculum and was annulled by boiling the Orion tissue. Freezing of both Majestic and Orion tissue aggregates destroyed the stimulus, but freezing followed by boiling or boiling followed by freezing did not. It is suggested that the failure of living Orion tissue aggregates to stimulate the growth of $\boldsymbol{P}$. infestans was a direct effect of their excluding the fungus.

\section{INTRODUCTION}

It was suggested by Muller \& Behr (1949) and by Muller (1958) that the resistance of the potato to Phytophthora infestans is the result of the action of 'phytoalexins' against the fungus. Further evidence for phytoalexins as antifungal substances was given by Spencer, Topps \& Wain (1957) and Cruickshank \& Perrin (1961). A nutritional basis for pathogenicity was suggested by Johnson (1953). Attempts have been made to study the interaction between host and fungus by using tissue cultures, notably by Morel (1944) and Coyier (1961). In the present paper the interactions between $\boldsymbol{P}$. infestans and free cell cultures and tissue aggregates of Solanum tuberosum var. Majestic (susceptible), and var. Orion (resistant to races 0,4 and others), are reported.

\section{METHODS}

Organisms. Phytophthora infestans race 4 was isolated from a leaf of the potato var. Duke of York during July 1964. At the time of the experiments it was pathogenic to var. Majestic and not pathogenic to var. Orion, when sporangial suspensions were placed on half tubers. Resistance to certain races of $\boldsymbol{P}$. infestans is known to be expressed in the tubers of Orion (Lapwood \& McKee, 1961).

Solanum tuberosum vars. Majestic and Orion. Both these potatoes were obtained from a commercial source and originally virus $X$ infected; they were grown as tissue cultures.

Media. Stock cultures of Phytophthora infestans were normally grown on slopes of French bean agar, at $22^{\circ}$. This medium was made by homogenizing $128 \mathrm{~g}$. 'Birds Eye' frozen 'Sliced green beans', with $800 \mathrm{ml}$. distilled water, filtering the mush through muslin, adding $2 \%(\mathrm{w} / \mathrm{v})$ Davis agar to the filtrate and autoclaving at $116^{\circ}$ for $10 \mathrm{~min}$. 
The tissue cultures of Solanum tuberosum were grown in a liquid medium of the following composition (made up in 1 l. glass-distilled water): mineral salts: $\mathrm{Na}_{2} \mathrm{SO}_{4}$, $800 \mathrm{mg}$.; $\mathrm{Na}_{2} \mathrm{HPO}_{4}, 33 \mathrm{mg}$; $\mathrm{KNO}_{3}, 80 \mathrm{mg}$; $\mathrm{KCl}, 65 \mathrm{mg}$.; $\mathrm{MgSO}_{4} .7 \mathrm{H}_{2} \mathrm{O}, 180 \mathrm{mg}$; $\mathrm{Ca}\left(\mathrm{NO}_{3}\right)_{2}, 400 \mathrm{mg}$. trace elements: $\mathrm{KI}, 1.5 \mathrm{mg}$.; $\mathrm{ZnSO}_{4}, 0.3 \mathrm{mg}$.; $\mathrm{H}_{3} \mathrm{BO}_{3}, 1.5 \mathrm{mg}$.; $\mathrm{MnCl}_{2}, \mathbf{0 . 2} \mathrm{mg}$. other additions: glycine, $3.0 \mathrm{mg}$.; thiamine, $0.1 \mathrm{mg}$.; nicotinic acid, $0.5 \mathrm{mg}$; pyridoxine, $0.8 \mathrm{mg}$.; Ca pantothenate, $2.5 \mathrm{mg}$.; EDTA (Na/Fe complex; $\mathrm{Na}_{2}$ EDTA, 0.0143 g. $+\mathrm{FeSO}_{4} .7 \mathrm{H}_{2} \mathrm{O}, 0.01069$ g.) $25 \mathrm{mg}$.; 2,4-dichlorophenoxyacetic acid, 6.0 mg.; $\alpha$-naphthylacetic acid, 0.1 mg.; sucrose, 20 g.; Difco yeast extract, 1 g.; coconut milk, $130 \mathrm{ml}$.

Establishment and maintenance of tissue cultures. Tubers of Solanum tuberosum were washed with detergent and distilled water, followed by surface sterilization for $10 \mathrm{~min}$. in a saturated solution of calcium hypochlorite. A plug of tissue was then removed from a tuber with a sterile no. 5 cork borer and surface sterilized in $95 \%(\mathrm{v} / \mathrm{v})$ ethanol in water $(1 \mathrm{~min}$.) followed by $10 \mathrm{~min}$. in saturated calcium hypochlorite. It was then washed twice in sterile glass-distilled water, cut into $0.5 \mathrm{~cm}$. discs and placed on the tissue culture medium solidified with $1 \%(\mathrm{w} / \mathrm{v})$ Davis agar.

The culture vessels were Pyrex boiling tubes, fitted with cotton-wool plugs and foil caps. Incubation was at $\mathbf{2 5}^{\circ}$. Callus formation was normally visible after 1-4 weeks. Once established in this manner, the calluses were transferred to $25 \mathrm{ml}$. of the liquid medium in $100 \mathrm{ml}$. Pyrex conical flasks, plugged and fitted with foil caps. These were agitated on a rotary shaker (80 rotations $/$ min.) at $25^{\circ}$. Under these conditions growth was continued, while the tissue mass soon broke down to give free cells and small tissue aggregates up to $0.5 \mathrm{~cm}$. diameter.

Stock callus cultures were maintained on the solid medium. The liquid cultures were topped up with fresh medium monthly. New liquid cultures were periodically initiated by using inocula from established clones.

Cell Petri plate experiments. In these experiments the medium used for liquid tissue culture was solidified with $1 \%(w / v)$ Davis agar. Petri plates were seeded with $1.5 \mathrm{ml}$. of potato free cell suspensions of equal turbidity, measured by eye. Greater accuracy could not be obtained (and in the context, was not necessary), because of the lack of homogeneity of these suspensions and the difficulty in controlling contamination. Control plates were inoculated with $1.5 \mathrm{ml}$. of the liquid tissue-culture medium, in which no potato cells had been grown. All plates were further seeded with 100 sporangia of Phytophthora infestans (obtained from 7-day cultures of the fungus) and suspended in $1 \mathrm{ml}$. of the liquid medium. Incubation was at $22^{\circ}$.

Potato tissue aggregate experiments. In these experiments pieces of tissue aggregate of about $40 \mathrm{~mm}$. diameter were placed near the edge, on opposite sides of a Petri plate. Each tissue aggregate was in contact with a separate streak of Phytophthora infestans sporangia (from 7-day cultures) suspended in liquid tissue-culture medium. The streaks were made with a glass loop of about $50 \mathrm{~mm}$. diameter. The object of these experiments was to observe the influence of the tissue aggregate on sporangia, along a possible diffusion path. It was originally intended that tissue pieces were to be placed on pre-formed streaks of sporangia, but in practice it was found more convenient to begin the streaks from tissue aggregates already placed in position on the agar. At the same time, a control streak of sporangial suspension was made 
in the centre of the plate. In later experiments the streaking of sporangia was dispensed with, and drops of tissue-culture liquid containing a known number of sporangia were placed on top of the tissue or directly on to the agar as controls.

\section{RESULTS}

Interaction of free potato cell suspensions and sporangia

Solanum tuberosum var. Majestic. When plates were simultaneously inoculated with Majestic cell suspensions and with 100 sporangia of Phytophthora infestans, growth of the $\boldsymbol{P}$. infestans was stimulated, and after some 10 days well developed colonies were present on many of the plates. Control plates, inoculated with fresh tissue-culture medium, showed no development of macroscopic colonies (see Plate 1, fig. 1).

Table 1. Colony formation on free-cell suspensions of Solanum tuberosum var. Majestic and var. Orion

Figures for ten Petri plates each inoculated with 100 sporangia of Phytophthora infestans.

\begin{tabular}{|c|c|c|c|}
\hline & & f potato & \\
\hline & Majestic & Orion & Control \\
\hline & & f $P$. infe & \\
\hline $\begin{array}{l}\text { Colony sizes (cm. diam.) } \\
\qquad 1.0 \\
>1.0 \\
>0.5\end{array}$ & $\begin{array}{c}8 \\
24 \\
9\end{array}$ & $\begin{array}{l}7 \\
8 \\
9\end{array}$ & $\begin{array}{l}1 \\
1 \\
0\end{array}$ \\
\hline Total sporangia germinated & $41 / 1000$ & $24 / 1000$ & $30 / 1000$ \\
\hline
\end{tabular}

Solanum tuberosum var. Orion. Similar inoculations of var. Orion potato cell suspensions showed some stimulation and colony formation by $\boldsymbol{P}$. infestans. Normally, in the cell Petri plates, all the $\boldsymbol{P}$. infestans sporangia which germinated produced colonies. The germination of $2-4 \%$ of the added sporangia was the normal for 7-day sporangia of this isolate.

It might be argued that the transfer of potato free cell suspensions to the environment of the agar plate would lead to the death of these cells. This was investigated by using 2,3,5-triphenyltetrazolium chloride. Estimates were made of the reduction of this compound to the red triphenylformazan by fresh cells and by cells removed at daily intervals from the surface of the plate. The results showed that the activity of the cells, as measured by colour production, was at a maximum immediately after transfer, fell to one-third of the maximum in $120 \mathrm{hr}$ and returned to two-thirds of the maximum activity within the next $24 \mathrm{hr}$. The activity remained at this value until the conclusion of the experiment at 12 days. After this time, the potato cells were seen to be growing on the agar plate. Considerable callus growth was observed after 6 weeks on plates inoculated with potato cell suspensions.

\section{Interaction of tissue aggregates and sporangia}

Normal tissues. Considerable development of the fungus took place within 3 days in that part of the streak of Phytophthora infestans sporangia in contact with the 
Majestic tissue aggregate. On the same plate the control streak and the streak in contact with Orion tissue aggregate showed only slight growth, even after 8 days (Pl. 1, fig. 2).

Treated tissues; Solanum tuberosum var. Majestic. Living, frozen $\left(-40^{\circ}, 30 \mathrm{~min}.\right)$, and boiled ( $1 \mathrm{~min}$.) tissue aggregates of var. Majestic were compared under the conditions outlined above. The results showed that the stimulus of Phytophthora infestans was decreased on boiling, and destroyed completely on freezing.

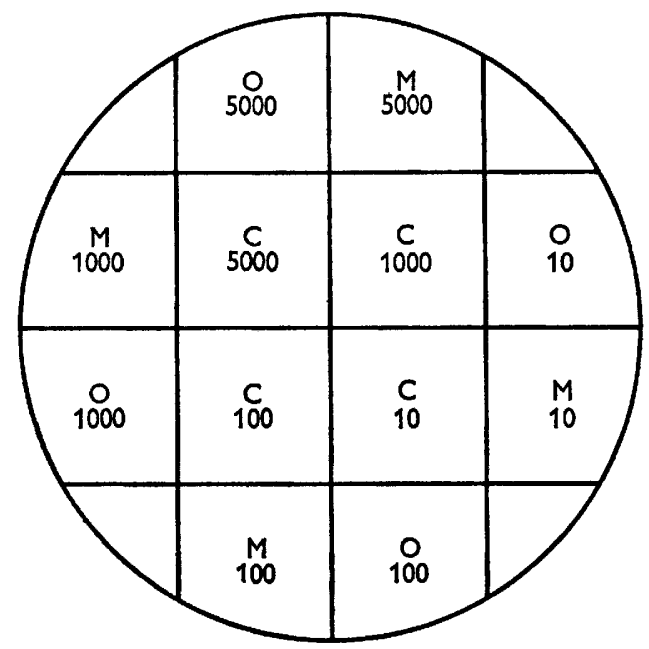

Fig. 1. Layout of experiment on relation of number of sporangia in inocula and resultant infection. $\mathrm{M}=$ Solanum tuberosum var. Majestic, $\mathrm{O}=$ var. Orion, $\mathrm{C}=$ control. 5000, 1000, 100 and $10=$ no. sporangia of Phytophthora infestans in inoculum drop.

Table 2. Stimulation of Phytophthora infestans by variously treated tissue aggregates of Solanum tuberosum var. Orion and var. Majestic

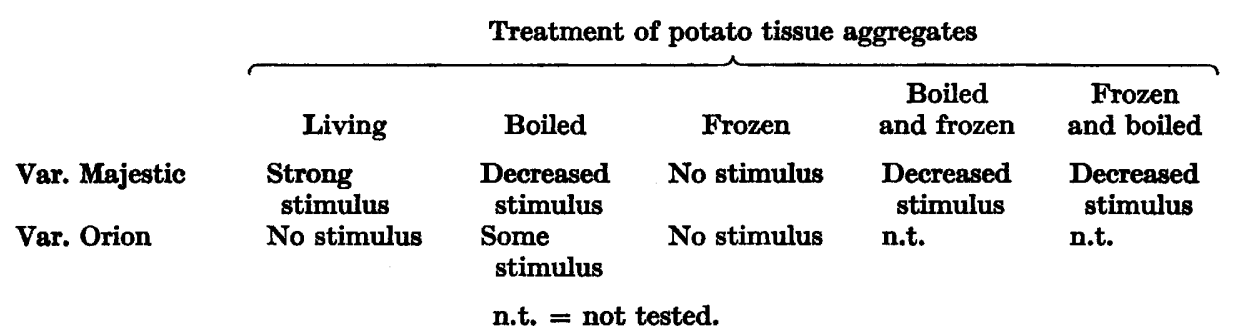

When previously frozen tissue was boiled, or boiled tissue was frozen, their stimulatory effect on Phytophthora infestans was the same as that obtained with tissue that had only been boiled (Pl. 2, fig. 3).

Treated tissues; Solanum tuberosum var. Orion. Living tissue aggregates of var. Orion were compared with boiled and frozen tissues. The living tissues and the frozen tissues did not stimulate Phytophthora infestans but growth was stimulated by the boiled tissue after 8 days (Pl. 2, fig. 4).

Effect of size of inoculum. It was of interest to discover whether the lack of stimulation by var. Orion, which might be interpreted as resistance to infection, 
could be overcome by increasing the size of the inoculum in the experiments. Petri plates, prepared as above, were marked off with lines into 12 squares, and the Orion and Majestic tissue aggregates laid out alternately as shown in Fig. 1. Inocula at $5000,1000,100$ and 10 sporangia, suspended in $0.02 \mathrm{ml}$. liquid medium, were applied to the tissues, and as control drops directly on the agar, in the order shown in the figure. When read at 7 days the distinction between Majestic and Orion tissues was maintained at all sizes of inoculum, except 5000 sporangia where a slight fungal activity appeared round the Orion tissue. This was no greater than the fungal growth obtained from the control on the agar alone. With the inoculum of 10 sporangia, no growth was seen either on the Majestic or on Orion tissue.

\section{DISCUSSION}

Although Phytophthora infestans is clearly dependent on its host, it can be grown alone on artificial media. The medium which supports the growth of potato tissue cultures also supports the growth of $\boldsymbol{P}$. infestans, and the growth of the fungus is relatively rapid when large inocula are used. However, when smaller inocula, e.g. suspensions containing about 100 sporangia, are added to this medium, germination takes place and usually a few colonies slowly become established. The addition of living Majestic potato cells to the surface of the medium stimulated the growth of the $\boldsymbol{P}$. infestans in a spectacular fashion. This is perhaps not unexpected. When Orion cells were inoculated in the same manner they also stimulated the growth of the fungus, relative to the control, but were not as potent as the Majestic cells. It is surprising that Orion cells not only supported growth, but stimulated it, for with the intact plant var. Orion the $\boldsymbol{P}$. infestans is rapidly excluded. Tomiyama, Takakuwa \& Takase (1958) found that $R$ genes were only expressed in slices of potato tissue which were more than ten cells in thickness. This may be analogous to the situation where Orion cell suspensions stimulated $\boldsymbol{P}$. infestans, while tissue aggregates did not.

Tissue aggregates of Majestic stimulated the growth of Phytophthora infestans, while tissue aggregates of Orion did not. We saw no sign of any toxic inhibition of the limited fungal growth in the vicinity of the Orion tissue. Since both living cell suspensions and dead (boiled) tissue aggregates of Orion stimulated, we must adduce that living tissue aggregates of Orion prevent the fungus from responding to the stimulus. When the fungus, at the point of infection, is excluded by the Orion cells, the stimulus can never be transported to the rest of the fungal mycelium.

Our observations of the sporangial streaks on the agar plate lead us to suppose that the tissues have little or no effect on the germination of the sporangia or on germ-tube development. It is only when the fungus reaches and infects the susceptible potato tissue that the fungal growth is stimulated. This stimulus is prolonged and such that the fungus luxuriates eventually to fill the Petri plate.

It is of interest that killing the Majestic and Orion tissue by boiling left the stimulus intact although diminished. In the Orion tissue, killing by boiling inactivated the resistance mechanism either by killing the cells which generated it or by destroying any antifungal substances present in the tissue. This suggests that the resistance is a property of living and not of dead tissues. Tissues killed by freezing to $-40^{\circ}$, at which temperature not all enzymes would be destroyed, behaved 
differently from the boiled cells, and both Majestic and Orion tissues so treated did not stimulate the fungus. It is possible that the resistance of Orion is left intact by this treatment and that resistance is developed in Majestic. However, a simpler explanation is that enzymic destruction of the stimulating substance takes place in both tissues after they have thawed. This view is further strengthened by the demonstration that when freezing was followed by boiling, or boiling was followed by freezing, the stimulus was preserved. The fact that a stimulus was demonstrated in dead (boiled) tissue of Majestic suggests that it is a normal tissue metabolite, and not formed in response to infection.

This work has shown very clearly that tissue aggregates of Solanum tuberosum var. Orion can support and stimulate the growth of Phytophthora infestans, when the aggregates are dead, so that there is no basic nutritional reason for the failure of $P$. infestans to invade the tissue. Further it has shown that the living Orion cells act only when they are infected and that there is as yet no evidence of a massive diffusion of toxic material from the resistant tissue, either before or after fungal invasion or attempted invasion. Finally the possible effect of tissue mass in determining the expression of the resistance (see Tomiyama et al. 1958) has been demonstrated under conditions where the complicating effect of an extensive wound surface is absent.

Our thanks are due to Dr A. Harrison for advice on methods of tissue culture and to the Agricultural Research Council for the support of one of us (D. S. I.).

\section{REFERENCES}

Coyrer, D. L. (1961). The biology and control of rose powdery mildew. Ph.D. Thesis, Univ. Wisconsin, p. 109.

Cruickshank, I. A. M. \& Perrin, Dawn R. (1961). Studies on phytoalexins. III. The isolation, assay and general properties of a phytoalexin from Pisum sativum. Aust. $J$. Biol. Sci. 14, 336.

Johnson, T. (1963). Variation in the rusts of cereals. Biol. Rev. 28, 105.

LAPwood, D. H. \& McKEE, R. K. (1961). Reaction of tubers of R-gene potato clones to inoculation with specialised races of Phytophthora infestans. Eur. Potato J. 4, 3.

Mones, G. (1944). Le developpement du Mildiou sur des tissus de Vigne cultures in vitro. C. r. hebd. Séanc. Acad. Sci., Paris, 218, 50.

Muller, K. O. (1958). Studies on phytoalexins. I. The formation and the immunological significance of phytoalexin produced by Phaseolus vulgaris in response to infections with Sclerotinia fructicola and Phytophtora infestans. Aust. J. Biol. Sci. 11, 275.

Muller, K. O. \& BeHr, L. (1949). Mechanism of Phytophthora resistance of potatoes. Nature, Lond. 163, 498.

SPEnCER, D. M., TopPS, J. H. \& WaIN, R. L. (1957). Fungistatic properties of plant tissues. An antifungal substance from the tissues of Vicia faba. Nature, Lond. 179, 651.

Tomiyama, K., Takakuwa, M. \& Takase, N. (1958). The metabolic activity in healthy tissue neighbouring the infected cells in relation to resistance to Phytophthora infestans in potatoes. Phytopath. Z. 31, 237. 


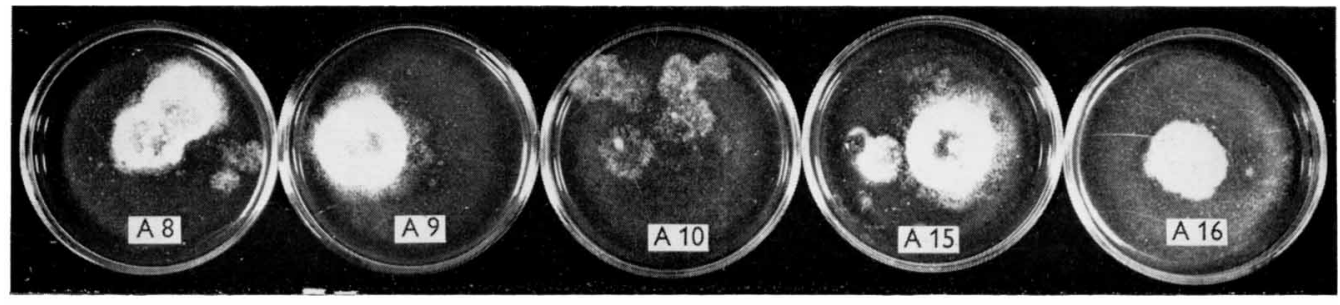

\section{Controls}
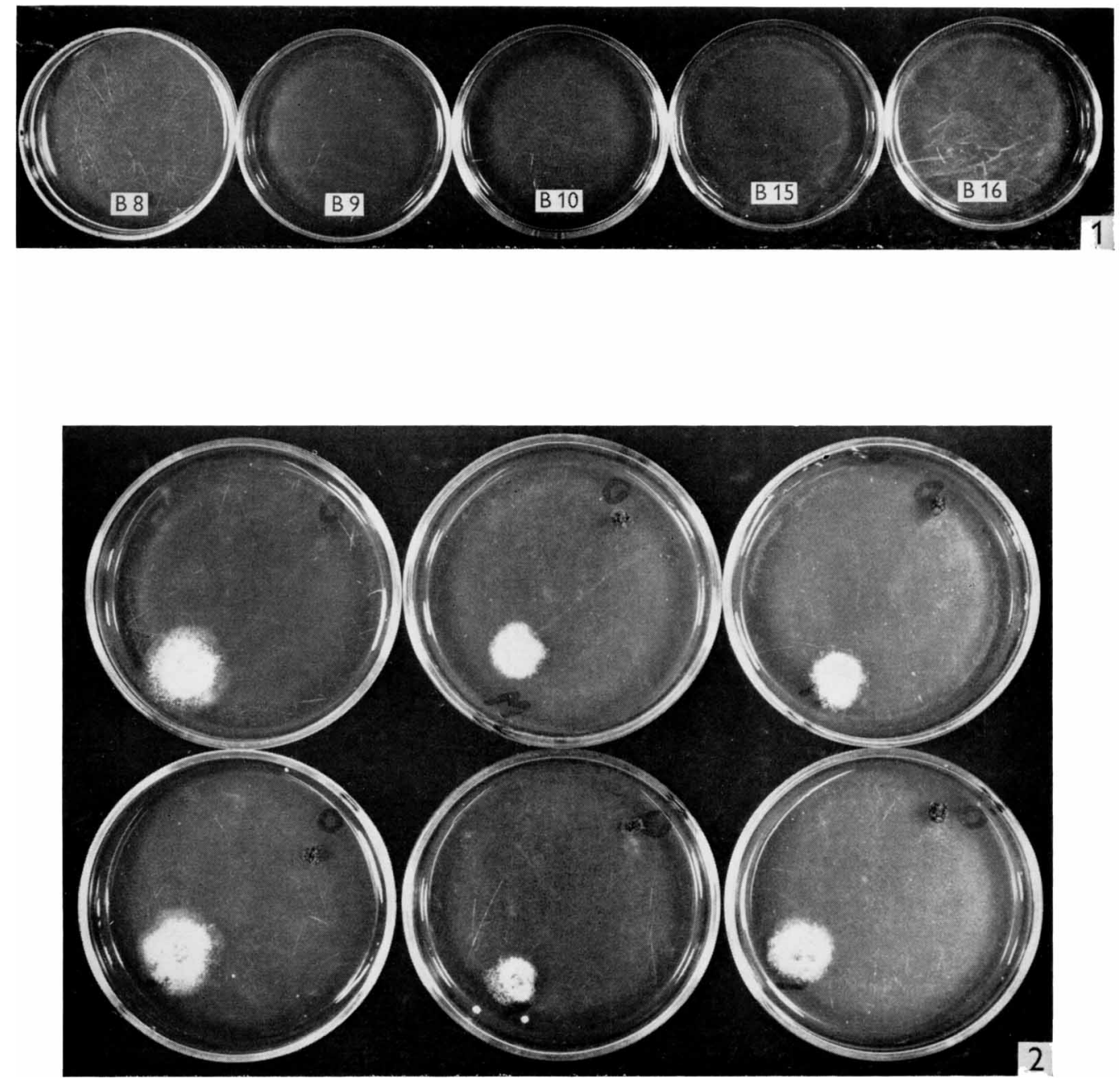

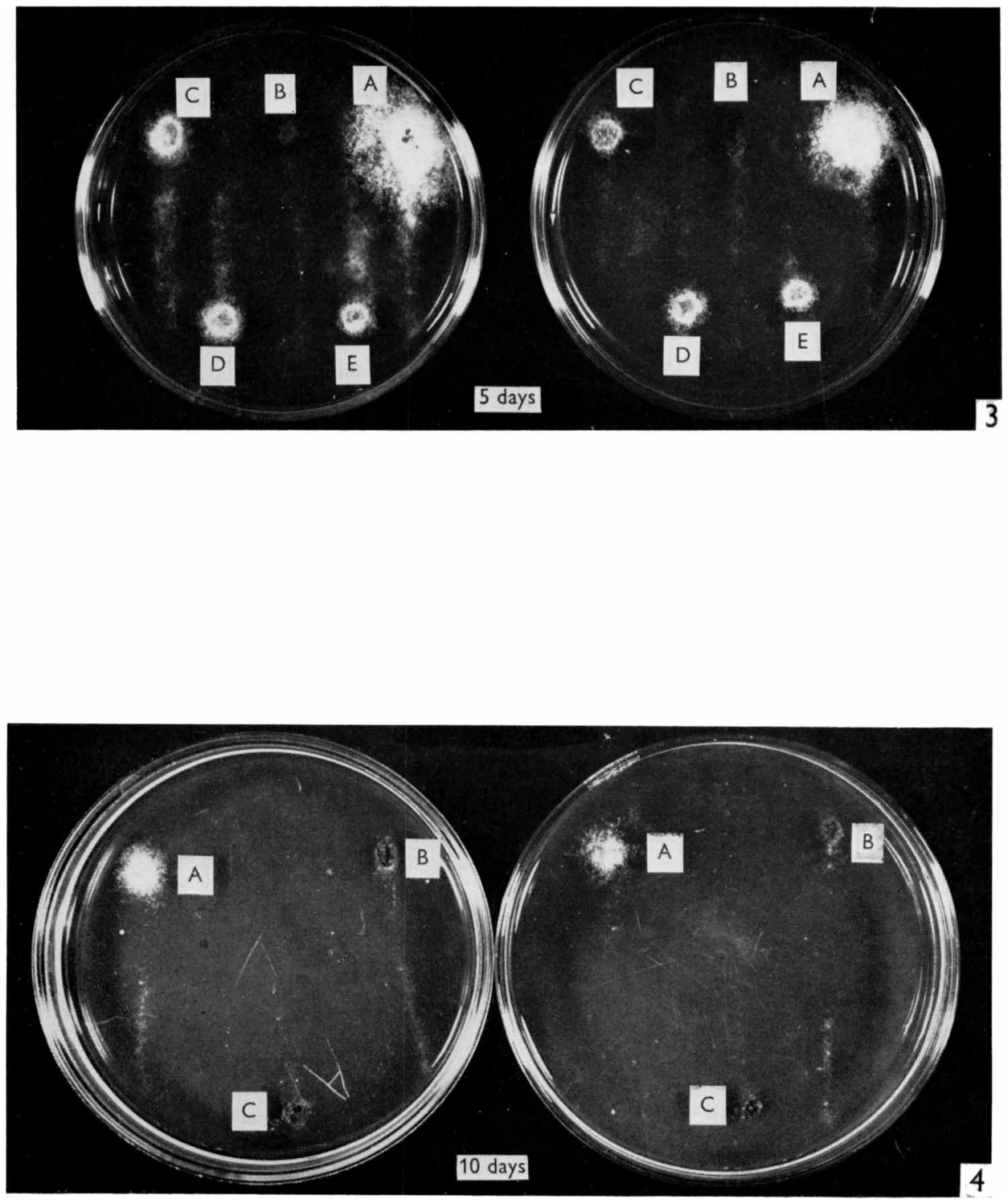

1). S. INGRAM AND N. F. ROBERTSON 


\section{EXPLANATION OF PLATES}

Prate 1

Fig. 1. Five examples of the interaction between 100 sporangia of Phytophthora infestans and cell suspensions of Solanum tuberosum var. Majestic tubers and five controls. 14 days.

Fig. 2. Six examples of the interaction between streaks of sporangia of Phytophthora infestans and tissue aggregates of tubers of Solanum tuberosum var. Majestic and var. Orion. 5 days.

\section{Plate 2}

Fig. 3. Two examples of the interaction between streaks of sporangia of Phytophthora infestans and pre-treated tuber tissue aggregates of Solanum tuberosum var. Majestic. 5 days. A, living; B, frozen, C, boiled; D, boiled then frozen; $E$, frozen then boiled.

Fig. 4. Two examples of the interaction between streaks of sporangia of Phytophthora infestans and pre-treated tuber tissue aggregates of $S$. tuberosum var. Orion. 10 days. A, boiled; B, living; C, frozen. 